\title{
Biosensors for environmental control
}

\author{
Isao Karube and Eiichi Tamiya \\ Research Laboratory of Resources Utilization, Tokyo \\ Institute of Technology, Nagatsuta, Midori-ku, Yokohama, \\ 227, Japan
}

\begin{abstract}
Various kinds of biosensors were developed for the environmental control. Microbial sensor consisting immobilized yeasts and oxygen probe has been applied to estimation of 5-day BOD. The response time of BOD sensor was less than $20 \mathrm{~min}$ and the minimum measurable BOD was 3 $\mathrm{mg} .1^{-1}$. Amperometric microbial sensor for ammonia was constructed with immobilized nitrifying bacteria and an oxygen probe. The minimum measurable concentration was 0.1 $\mathrm{mg} 1^{-1}$. The output of the sensor was almost constant for more than 10 days and 200 assays. A sensor consisting of the aerobic recombinant-deficient bacteria and the oxygen electrode could be applied to the preliminary screening of chemical mutagens and carcinogens. Preliminary screening of mutagens was possible within a hour. In addition, other biosensors for nitrite, sulfite ion and methane gas were described.
\end{abstract}

\section{INTRODUCTION}

The determination of organic compounds is very important in environmental analysis. As various compounds are contained in test sample, for example, selective determination methods of these compounds are required. Most analysis of organic compounds can be performed by spectrophotometric methods. However, these methods required for a long reaction time and complicated procedures.

On the other hand, electrochemical monitoring devices employing immobilized biocatalysts (biosensors) have definite advantages(ref. $1,2,3$ ). Various sensors using immobilized enzymes and microorganisms were developed for environmental analysis. The microbial sensor consisted of immobilized living whole cells and an oxygen electrode. When the microbial sensor is inserted in a sample solution containing organic compounds, the organic compounds are diffused to microbial cells in a membrane and they are assimilated by the microbial cells. Therefore, the respiration activity (oxygen uptake) of the microbial cells rises after assimilation of organic compounds. Thus, the amount of oxygen diffused to the oxygen probe decreases and it is measured from the current of the electrode.

Another sensors are based on the amperometric or potentiometric determination of microbial metabolites. These sensors consisted of immobilized microbial cells and a fuel cell type electrode or an ionselective electrode or a carbon dioxide electrode.

This paper summarize principle and application of microbial sensors for environmental control.

\section{BOD SENSOR}

Biochemical oxygen demand (BOD) is one of the most important and widely used tests in the measurement of organic pollution. The BOD test measures biodegradable organic compounds in waste waters; it requires, in practice, a long incubation period, 5 days at $20^{\circ} \mathrm{C}$, and considerable skill. Despite these limitation the 5-day BOD test has remained a standard pollutionmonitoring tool since 1936. Therefore, rapid and reproducible methods are desirable for the BOD test. Recently, microbial sensors consisting of immobilized yeasts and an oxygen probe have been developed for estimation of 5-day BOD(ref. 4,5,6,7). Immobilized Trichosporon cutaneum was employed for the microbial sensor for BOD.

The scheme of the microbial sensor is illustrated in Figure 1. An 


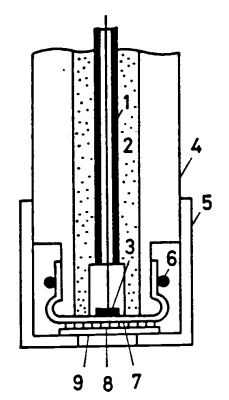

Fig. 1. Scheme of the microbial electrode for BOD estimation 1: Aluminum anode, 2: Electrolyte, 3: Platinum cathode, 4: Insulator, 5: Bored cap, 6: O-ring, 7: Teflon membrane, 8: Immobilized microorganisms, 9: Acetylcellulose membrane

oxygen probe (Model 3021, Denki Kagaku Keiki Co.) consisted of a Teflon membrane (thickness $50 \mu \mathrm{m}$ ), a platinum cathode, an aluminum anode and saturated potassium chloride electrolyte. The porous membrane (diameter $14 \mathrm{~mm}$ ) retaining the microorganisms was placed on the Teflon membrane of the oxygen probe so that the microorganisms were trapped between the two membranes and the porous membrane was fixed with a cap as illustrated in Figure 1 .

When the sample solution containing glucose and glutamic acid was injected into the system, organic compounds permeated through the porous membrane and were assimilated by the immobilized microorganisms. Consumption of oxygen by the immobilized microorganisms began and caused a decrease in dissolved oxygen around the membranes. As a result, the current of the electrode decreased markedly with time until a steady state was reached within $18 \mathrm{~min}$. The steady state indicates the consumption of oxygen by microorganisms and that diffused from a sample solution to the membrane were in equilibrium. The steady state current depended on BOD of the sample solution. Then the current of the microbial electrode sensor finally returned to the initial level. The response time of the microbial sensor (time required for the current to reach steady state) depended on the kind of sample solution. The response time was $8 \mathrm{~min}$ for acetic acid solution, and $18 \mathrm{~min}$ for glucose solution. Therefore, injection time of $20 \mathrm{~min}$ was employed for further work.

A linear relationship was observed between the current difference (between initial and steady state current) and the 5-day BOD of the sfandard solution below $60 \mathrm{mg} 1^{-1}$. The minimum measurable BOD was $3 \mathrm{mg} 1^{-1}$. The current was reproducible within $+6 \%$ of the relative error when BOD $40 \mathrm{mg} 1^{-1}$ of the standard solution was employed. The standard deviation was BOD 1.2 $\mathrm{mg} 1^{-1}$ in 10 experiments. The current means the current differences hereinafter.

The microbial sensor was applied to estimation of 5-day BOD for untreated waste waters from a fermentation factory. The 5-day BOD of the waste waters was determined by JIS method (Japanese Industrial standard Committee, 1974). Good comparative results were obtained between BOD estimated by the microbial electrode and those determined by JIS method. Regression coefficient was 1.2 in 17 experiments and the ratios (BOD estimated by the microbial electrode/5-day BOD determined by JIS method) were in the range from 0.85 to 1.36. This variation might have been caused from change in composition of organic waste water compounds. Therefore, the effect of various pure compounds on BOD estimated by the microbial sensor was examined. The sensor showed low BOD values compared with the 5-day BOD when lactose and soluble starch were employed for experiments. This might be caused from the slow decomposition rate of these compounds by the immobilized yeasts. On the other hand, the sensor showed high BOD values compared with the 5-day BOD when acetic acid and ethyl alcohol were employed. These results suggested the oxidation rate of acetate and ethyl alcohol to be faster than that of some standard substrates such as glucose and glutamic acid. No large difference was observed between the BOD determined by both methods when other substrates were employed for experiments. Therefore, waste waters containing substrates such as acetic acid and alcohols showed high BOD values. Furthermore, the BOD of various kinds of untreated industrial waste waters were estimated by the sensor. Table 1 shows a comparison between BOD estimated by the sensor and that determined by JIS 5-day method. As shown in Table 1, the BOD values estimated by the sensor depended on compounds in waste waters.

stable responses to the standard solution (BOD $20 \mathrm{mg} \mathrm{l}^{-1}$ ) were observed for more than 17 days (400 tests). Fluctuations of the current and the base line (endogeneous level) were within $\pm 20 \%$ and $\pm 15 \%$ respectively for 17 days. The microbial electrode could be used for long time for the estimation of BOD. 
Table 1.Comparison between BOD estimation by the microbial electrode and that determined by 5-day method

\begin{tabular}{|c|c|c|c|}
\hline \multirow[t]{2}{*}{ Waste water } & \multicolumn{2}{|l|}{ BOD } & \multirow{2}{*}{$\begin{array}{l}\text { Difference } \\
(\%)\end{array}$} \\
\hline & $\begin{array}{l}\text { Microbial electrode } \\
\left(\mathrm{mg} \mathrm{l^{-1 }}\right)\end{array}$ & $\begin{array}{l}\text { 5-day method } \\
\left(\mathrm{mg} \mathrm{l^{-1 }}\right)\end{array}$ & \\
\hline $\begin{array}{l}\text { Food factory } \\
\text { (soup Co.) }\end{array}$ & 155 & 152 & 2 \\
\hline $\begin{array}{l}\text { Food factory } \\
\text { (Starch } \\
\text { Saccharifying }\end{array}$ & 4250 & 4000 & 6 \\
\hline Palm oil mill & 12400 & 9840 & 26 \\
\hline
\end{tabular}

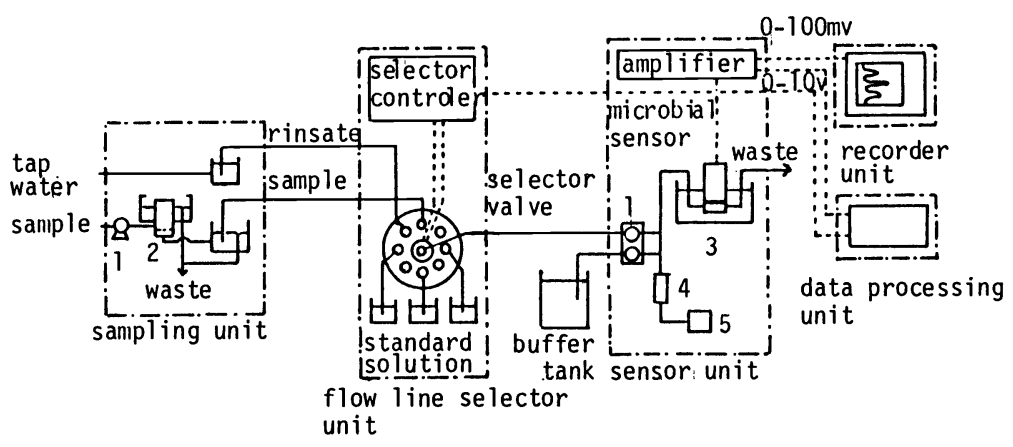

Fig. 2. Schematic diagram of continual measuring system for BOD

In conclusion, the microbial sensor using immobilized yeasts appears quite promising and very attractive for the estimation of the 5-day BOD of industrial waste waters. Figure 2 shows schematic diagram of continual measuring system for BOD. This system consisted of sampling unit, flow line selector unit, sensor unit, data processing unit and recorder unit. BOD of waste waters could be continuously estimated by the system.

\section{AMMONIA SENSOR}

The determination of ammonia is important in clinical, environmental, and industrial process analysis. An ammonia gas electrode consisting of a combined glass electrode and a gas permeable membrane is usually used for this purpose(ref. 8,9 ). In this case, the determination must be performed under strong alkaline conditions (above $\mathrm{pH} 11$ ). The ammonia electrode is based on potentiometric detection of ammonia. However, volatile compounds such as amines often interfere with the determination of ammonia. Therefore, an ammonia sensor based on amperometry is desirable for the electrochemical determination of ammonia.

Nitrifying bacteria contains two genera of bacteria. One genus (i.e., Nitrosomonas sp.) of bacteria utilizes ammonia as the sole source of energy and oxygen is consumed by the respiration. The other genus (i.e., Nitrobacter sp.) of bacteria oxidizes nitrite to nitrate.

$$
\begin{aligned}
& \mathrm{NH}_{3}+3 / 2 \mathrm{O}_{2} \stackrel{\text { Nitrosomonas }}{\stackrel{\text { sp. }}{\longrightarrow} \mathrm{NO}_{2}^{-}+\mathrm{H}_{2} \mathrm{O}+\mathrm{H}^{+}} \\
& \mathrm{NO}_{2}{ }^{-}+1 / 2 \mathrm{O}_{2} \stackrel{\text { Nitrobacter }}{\stackrel{\text { sp. }}{\longrightarrow}} \mathrm{NO}_{3}^{-}
\end{aligned}
$$

The oxidation of both substrates $\left(\mathrm{NH}_{3}, \mathrm{NO}_{2}\right)$ proceeds at a high rate, and oxygen uptake by the bacteria can be directly determined by the oxygen electrode attached to the immobilized bacteria. Therefore, ammonia is amperometrically determined by the microbial sensor using immobilized nitrifying bacteria and an oxygen electrode.

The $\mathrm{pH}$ of a sample solution had to be kept sufficiently above the pK value for ammonia $\left(9.1\right.$ at $\left.30^{\circ} \mathrm{C}\right)$ because ammonium ions cannot pass through the gas permeable membrane. 


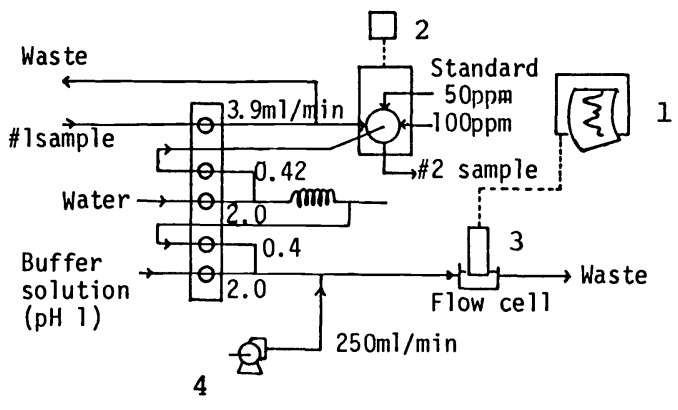

Fig. 3. Ammonia sensor system 1: Recorder,

2: Timer,

3: Ammonia electrode, 4: Air pump

A linear relationship was observed between the current decrease (the current difference between the initial and the steady state) and the ammonia concentration below $42 \mathrm{mg} 1^{-1}$ (current decrease $4.7 \mu \mathrm{A}$ ). The minimum concentration for the determination of ammonia was $0.1 \mathrm{mg}^{-1}$ (signal to noise, 20; reproducibility, \pm 58 . The reproducibility of the current decrease was examined by using the same sample. The current decrease was reproducible within $+4 \%$ of the relative error when a sample solution containing $21 \mathrm{mg} l^{-1}$ of ammonium hydroxide was employed. The standard deviation was $0.7 \mathrm{mg} 1^{-1}$ in 20 experiments.

Thus the amperometric determination of ammonia became possible by the microbial sensor. The sensitivity of the microbial sensor was almost at the same level as that of a glass electrode, and its minimum measurable concentration was $0.1 \mathrm{mg} 1^{-1}$. The selectivity of the microbial sensor for ammonia was examined. The sensor did not respond to volatile compounds such as acetic acid, ethyl alcohol, and amines (diethylamine, propylamine, and butylamine) or to involatile nutrients such as glucose, amino acids, and metal ions (potassium ion, calcium ion, and zinc ion).

Nitrifying bacteria, which utilize ammonia, did not assimilate acetic acid, ethyl alcohol, volatile amines, glucose, amino acids, and metal ions. Therefore, these substances did not affect the determination of ammonia by the sensor. Therefore, selectivity of this microbial electrode became satisfactory. The long-term stability of the microbial sensor was examined with a sample solution containing $33^{\mathrm{mg} 1^{-1}}$ of ammonia. The current output of the sensor was almost constant for more than 10 days and 200 assays. Therefore, the microbial sensor can be used for a long time for the assay of ammonia.

The microbial sensor was applied to the determination of ammonia in waste waters. The sample was diluted with the glycine-NaCl-NaOH buffer (50 times) and employed for experiments. The concentration of ammonia was determined by the electrochemical sensor and the conventional method.

Good comparative results were obtained between ammonia concentrations determined by both methods (correlation coefficient 0.9). Therefore, the sensor proposed gives an economical and reliable method for assay of ammonia. Figure 3 shows the sensor system for continuous ammonia determination in waste waters. Ammonia in waste waters of a nitrification test plant could be determined by the system.

\section{NITRITE SENSOR}

The principal gaseous oxides of nitrogen of interest in air pollution sampling and analysis are nitric oxide (NO), and nitrogen dioxide ( $\left.\mathrm{NO}_{2}\right)$. During the combustion of all types of fossifuels at flame temperature, less than 0.18 up to about 0.58 nitric oxide is formed, along with much smaller amounts of nitrogen dioxide. When discharged to the atmosphere, nitric oxide oxidizes at a measurable rate to nitrogen dioxide. Nitrogen dioxide is the most reactive or the gaseous oxides of nitrogen and is a primary absorber of sunlight in photochemical atomospheric reactions that produce photochemical smog(ref. 13). Therefore, the determination of nitrogen dioxide is important in environmental and industrial process analyses.

Nitrobacter sp. utilize nitrite as the sole source of energy as described above and oxygen is consumed by the respiration as follows:

$$
2 \mathrm{NO}_{2}{ }^{-}+\mathrm{O}_{2} \stackrel{\text { Nitrobacter }}{\longrightarrow} 2 \mathrm{NO}_{3}{ }^{-}
$$




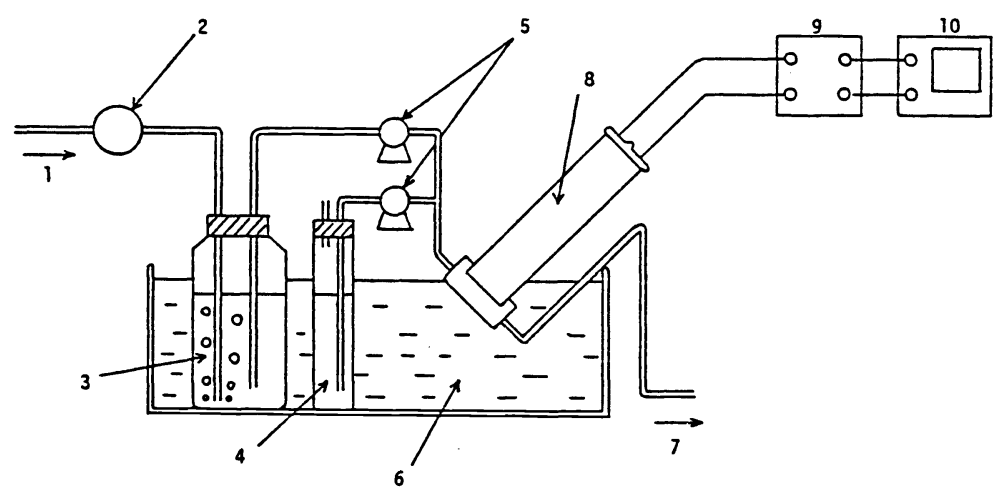

Fig. 4. Schematic diagram of the sensor system 1: $\operatorname{Air}\left(280 \mathrm{ml} \mathrm{min} \mathrm{m}^{-1}\right), 2:$ Pump, 3: $\mathrm{O}_{2}$ saturated buffer(pH 2), 4: Sample solution, 5: Peristaltic pumps, 6: Incubator $\left(30^{\circ} \mathrm{C}\right), 7$ : Waste, 8: Microbial electrode, 9: Amplifier, 10: Recorder

oxygen uptake by the bacteria can be directly determined by the oxygen electrode attached to the immobilized bacteria. Therefore, $\mathrm{NO}_{2}$ generated in the buffer ( $\mathrm{pH} 2.0)$ can be determined by the microbial sensor using immobilized Nitrobacter sp. and an oxygen electrode(ref. 14).

A nitrogen dioxide electrode using a gas permeable membrane, immobilized Nitrobacter sp. and an oxygen electrode is described. The porous membrane retaining the immobilized bacteria was cut into a circle and soaked in the buffer. This immobilized bacterial layer was carefully attached on the surface of a Teflon membrane of the oxygen electrode,. and covered with a gas-permeable Teflon membrane and fastened with rubber rings.

Figure 4 shows a schematic diagram of the system which consisted of a jacketed flow cell with microbial sensor, a peristaltic pump, an amplifier, and a recorder. When the sample solution (sodium nitrite solution) is transferred into the flow cell, nitrous ions change to nitrogen dioxide gas at $\mathrm{pH} 2.0$.

Then nitrogen dioxide passes through the gas permeable membrane. Nitrogen dioxide gas changes to nitrous ions in the bacterial layer and are utilized by Nitrobacter sp. as the sole source of energy. The consumption of oxygen around the membrane is determined by the oxygen electrode. Therefore, the concentration of sodium nitrite can be indirectly determined from the current decrease of the oxygen electrode.

When a sufficient quantity of the bacteria is immobilized in the sensor, the current of the sensor for a sodium nitrite solution depends mainly on the rate of diffusion of nitrite from the sample solution to the immobilized bacteria. The $\mathrm{O}_{2}$ content in sample solutions were checked using differential sensor system (the sensor without immobilized bacterial layer and with immobilized bacterial layer) to prevent an influence of oxygen in the sample solution. Therefore, the steady state current depended on the concentration of sodium nitrite. The differences between the initial and steady state currents were directly proportional to the concentration of sodium nitrite. When only the buffer solution was transferred to the flow cell, the current of the microbial sensor returned to its initial level within about $12 \mathrm{~min}$. The next sample could then be determined by continuously using the same sensor system.

A linear relationship was observed between the current decrease (the current difference between the initial and the steady state) and the sodium nitrite concentration below $0.59 \mathrm{mM}$ (current decrease $0.63 \mu \mathrm{A}$ ). At greater than $0.65 \mathrm{mM}$ sodium nitrite, a linear relationship was not observed between the currents and concentrations. The minimum concentration for the determination of sodium nitrite was $0.01 \mathrm{mM}$ (signal to noise, 20: reproducibility, $\pm 5 \%$ ). The reproducibility of the current decrease was examined by using the same sample. The current decrease was reproducible within $\pm 4 \%$ of the relative error and the standard deviation was $0.01 \mathrm{mM}$ in 25 experiments when a sample solution containing $0.25 \mathrm{~mm}$ of sodium nitrite was employed.

Thus the amperometric determination of sodium nitrite became possible using the microbial sensor. The selectivity of the microbial sensor for sodium nitrite was examined. The sensor did not respond to volatile compounds such as acetic acid, ethyl alcohol, and amines (diethylamine, propylamine, and butylamine) or to involatile nutrients such as glucose, amino acids, and ions (potassium and sodium ions). Therefore, the 
selectivity of this microbial sensor was satisfactory in the presence of these different substances. The long term stability of the microbial sensor was examined with a sample solution containing $0.25 \mathrm{~mm}$ of sodium nitrite. The current output of the sensor was almost constant for more than 21 days and 400 assays. The microbial sensor can be used to assay sodium nitrite for a long period. In the same experiments the concentration of sodium nitrite was determined by both the sensor proposed and the conventional method (dimethyl-a-naphtylamine method). A good correlation was obtained between the sodium nitrite concentrations determined by the two methods (correlation coefficient 0.99 ).

\section{SULFITE ION SENSOR}

The determination of sulfite and sulfur dioxide in waste waters and atmosphere is important in any environmental analysis. There is an ever increasing demand for new, simple and inexpensive methods for the measurement and control of sulfite and sulfur dioxide pollution.

Hepatic microsome is a subcellular organelle, which contains many different oxidases, and enzymatically oxidizes sulfite to sulfate with consumption of molecular oxygen(ref. 15). An amperometric organelle sensor for the determination of sulfite, composed of immobilized microsome particles, a gas-permeable Teflon membrane and an oxygen electrode. Rat liver s9 fraction $(100 \mu l)$ containing microsome was filtered through the porous acetylcellulose membrane. The quantity of organelle immobilized was equivalent to $2.7 \mathrm{mg}$ protein. The microsome was retained on the acetylcellulose membrane. The organelle membrane was attached to the surface of the Teflon membrane of the oxygen electrode and covered with another Teflon membrane.

When the sample solution of sulfite was injected, sulfur dioxide permeated through the Teflon membrane and was oxidized by the microsome containing sulfite oxidase. Consumption of oxygen by the microsome began simultaneously and caused a decrease in dissolved oxygen around the membrane. As a result, the current of the sensor decreased markedly with time until a steady state was reached after $10 \mathrm{~min}$. When a sufficient quantity of the microsome was employed in the sensor, the current of the sensor depended mainly on the rate of diffusion of sulfur dioxide from the sample solution to the immobilized organelle. The steady state current thus depended on the concentration of sulfite ions.

The response of the organelle sensor increased with increasing amount of organelle, and became constant at an amount of organelle exceeding $2.7 \mathrm{mg}$ protein. An organelle amount equivalent to $7.7 \mathrm{mg}$ protein was therefore immobilized on the acetylcellulose membrane. In this case, diffusion of substrate (sulfite) may also be rate determining.

A linear relationship was obtained between the steady state current and the sulfite ion concentration below $3.4 \times 10^{-4} \mathrm{M}$. The minimum concentration for determination was $0.6 \times 10^{-4} \mathrm{M}$. The currents were reproducible with an average relative error of $7 \%$ when a sample solution containing $2.8 \times 10^{-4} \mathrm{M}$ of sulfite ion was used. The standard deviation was $0.3 \times 10^{-4} \mathrm{M}$ in 30 experiments.

The selectivity of the organelle sensor for sulfite is presented in Table 2. The sensor did not respond to nonvolatile compounds such as sucrose, glucose, pyruvic acid, sulfate, phosphate ions, and ammonium ions, since the organelle sensor was covered with the gas-permeable Teflon membrane, and nonvolatile nutrients could not penetrate through this membrane. Volatile compounds such as formic acid, acetic acid, propionic acid, n-butyric acid, methyl alcohol, and ethyl alcohol can permeate through the Teflon membrane, but no current was obtained from these compounds,

Table 2. Response of sulfite sensor to various compounds

\begin{tabular}{ll}
\hline Compound & Current decrease $(\mu \mathrm{A})$ \\
\hline $\mathrm{SO}_{3}^{2-}$ & 8.5 \\
$\mathrm{SO}_{4}^{2-}$ & 0 \\
$\mathrm{NO}_{2}^{-}$ & 2.0 \\
$\mathrm{NO}_{3}^{-}$ & 0 \\
$\mathrm{C}_{2} \mathrm{H}_{5} \mathrm{OH}$ & 0 \\
$\mathrm{CH}_{3} \mathrm{OH}$ & 0 \\
$\mathrm{HCOOH}$ & 0 \\
$\mathrm{NH}_{3}$ & 0 \\
$\mathrm{CH}_{3} \mathrm{COOH}$ & 0 \\
$\mathrm{C}_{6} \mathrm{H}_{12} \mathrm{O}_{6}$ & 0 \\
\hline
\end{tabular}


because they are not oxidized by the enzyme system of the microsome, When the sensor was inserted into a sample solution containing $2.8 \times 10^{-4} \mathrm{M}$ nitrite, a current decrease was observed $(2.0 \mu \mathrm{A})$. This shows that nitrite could interfere with the determination of sulfite,, but the response of the sensor to nitrite ion was only $23.5 \%$ of that to sulfite ion.

Many enzyme electrodes have been developed and applied to clinical, food, and environmetnal analyses, but no such electrodes have previously been developed for the determination of sulfite. This might be due to the difficulty of isolating sulfite oxidase, and for this reason the organelle was used as a source of the enzyme. The life of the organelles depends on storage conditions; they retain sulfite oxidase activity for 6 months when stored in a frozen state at $-20^{\circ} \mathrm{C}$. The electrode current is reproducible within an average relative error of $7 \%$ when the organelle membrane used for analysis is replaced with new membrane prepared from stored organelles. While the stability of the organelle sensor proposed is still poor (life of 2 days and 20 assays) when used and stored at $37^{\circ} \mathrm{C}$, because of the instability of the sulfite oxidase at this temperature, the preparation and exchange of an organelle membrane are very easy and replacement takes only 1 min.

\section{METHANE GAS}

Methane is a clean fuel and major component of city gas ( $88 \%$ methane) but forms an explosive mixture with air (5-14\% methane). A methane oxidizing bacterium, which grows well, has been isolated from a natural source, grown in pure culture, and identified as a new species, Methylomonas flagellata.

M. flagellata utilizes methane as its sole source of energy; and oxygen is consumed by respiration as follows;

$$
\mathrm{CH}_{4}+\mathrm{NADH}_{2}+\mathrm{O}_{2} \longrightarrow \mathrm{CH}_{3} \mathrm{OH}+\mathrm{NAD}+\mathrm{H}_{2} \mathrm{O} \text { (ref. 16) }
$$

M. flagellata was immobilized in acetylcellulose filters with agar. The microbial sensor system, schematically illustrated in Figure 5, is composed of an immobilized microorganism reactor (300 $\mathrm{mg}$ immobilized cells/reactor), a control reactor, and two oxygen electrodes. Methane gas was introduced into both reactors by a pump at a controlled flow rate. The difference between the output currents of the two electrodes was related to the amount of methane in the flow lines. When sample gas containing methane was transferred to the immobilized bacteria cells, methane was assimilated by the microorganisms. Oxygen was then consumed by the microorganisms so that

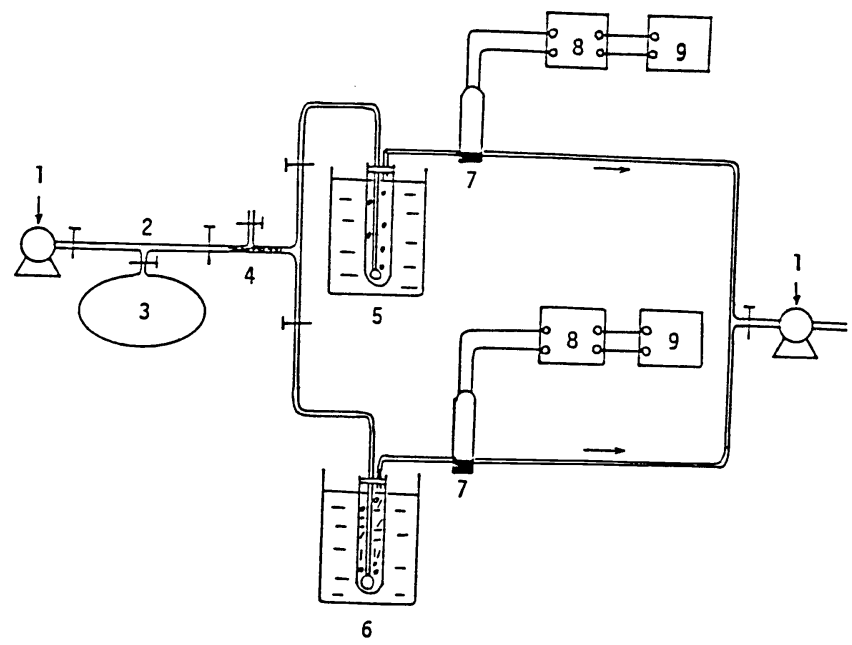

Fig. 5. Schematic diagram of methane gas sensor

1: Pump, 2: Gas sampler, 3: Sample gas, 4: Cotton filter, 5: Reference reactor, 6: Methane oxidizing bacteria reactor, 7: Oxygen electrode, 8: Amplifier, 9: Recorder 


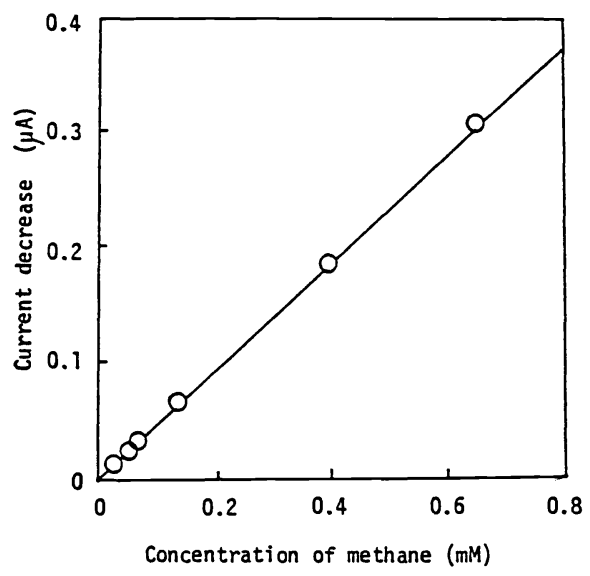

Fig. 6. Calibration curve for methane gas sensor

Experimental conditions: $30^{\circ} \mathrm{C}$, $\mathrm{pH} 7.2$, gas flow velocity $80 \mathrm{ml} \mathrm{min}^{-1}$ and cell content $300 \mathrm{mg}$ wet cells in $30 \mathrm{ml}$ wet filter.

the concentration of dissolved oxygen in the reactor decreased. The current decreased and reached a steady-state, which indicated that the consumption of oxygen by the microorganisms and the diffusion of oxygen from the sample gas to the immobilized bacteria were in equilibrium. The steady-state current depended on the concentration of methane. When air passed through the flow reactor, the current of the sensor returned to its initial level within $1 \mathrm{~min}$. The response time required for the determination of methane gas was $1 \mathrm{~min}$. The total time required for an assay of methane gas by this steady-state method was 2 min.

Figure 6 shows the calibration curve for this microbial sensor system. A linear relationship was observed between the current difference, between the electrodes, and the concentration of methane (below $6.6 \mathrm{~m} M$ ). The minimum concentration for the determination was $13.1 \mu \mathrm{M}$. The current decrease was reproducible within $+5 \%$ in 25 experiments with sample gas containing $0.66 \mathrm{mM}$ methane. The maximum current difference was observed at $30^{\circ} \mathrm{C}$, which was used constant below an air flow rate of $8.0 \mathrm{ml} \mathrm{min}^{-1}$, but above this flow rate the current difference decreased. The long-term stability of the microbial sensor was examined with a sample gas containing $0.66 \mathrm{~mm}$ methane. The current output was almost constant for more than 20 days and 500 assays. In the same experiment a good correlation was obtained between the methane concentrations determined by the electrochemical sensor and conventional gas chromatography methods (correlation coefficient 0.97). This sensor system can be used to determine the content of methane gas in the atmosphere. In conclusion, this microbial sensor system which used immobilized $\mathrm{M}$. flagellata appears promising and a very attractive system for the rapid and continuous determination of methane.

\section{MUTAGEN SENSOR}

Long-term carcinogenicity tests with laboratory mammals are not only time-consuming but also demanding resources. The mutagenic activity of carcinogens has recently been confirmed in a great number of cases. The existence of a high correlation between the mutagenicity and carcinogenicity of chemicals is now evident. The use of microbial systems is important for a survey of mutagenic chemicals. Recently, a number of microbial methods for detecting the various types of mutagens have been developed. Microbial reversion assays using Salmonella typhimurium(ref. 17) or Escherichia coli have been employed for screening tests of chemical carcinogens(ref. 18). A method named "rec-assay" utilizing Bacillus subtilis has also been proposed for screening chemical mutagens and carcinogens. These methods are more rapid and simple than the carcinogen test using animals. However, the microbial reversion assays and the "rec-assay" still require a lengthy incubation of bacteria and complicated procedures. 


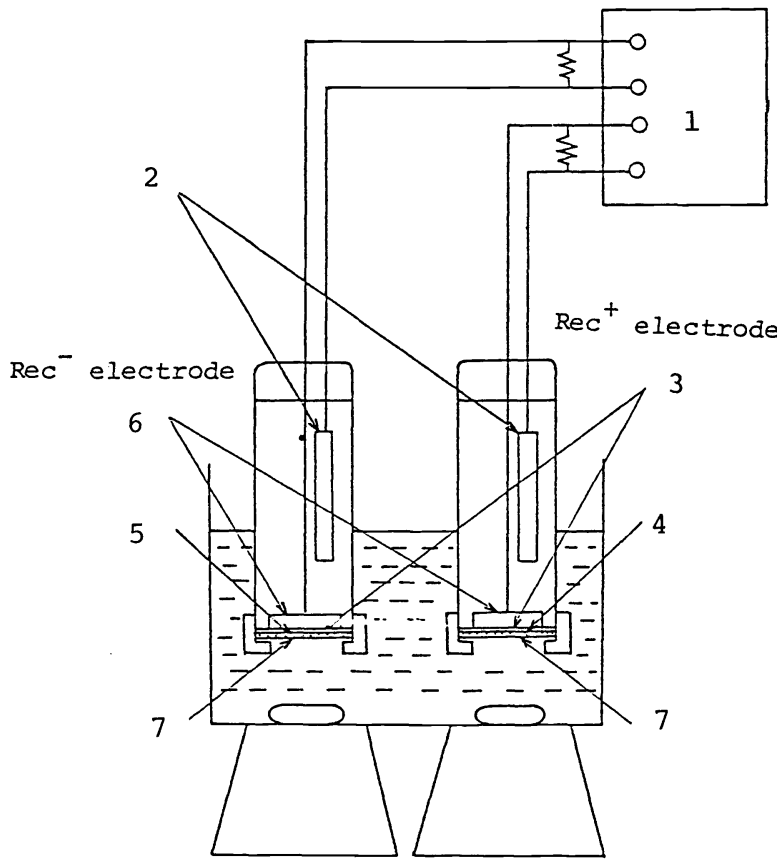

Table 3. Response to various mutagens

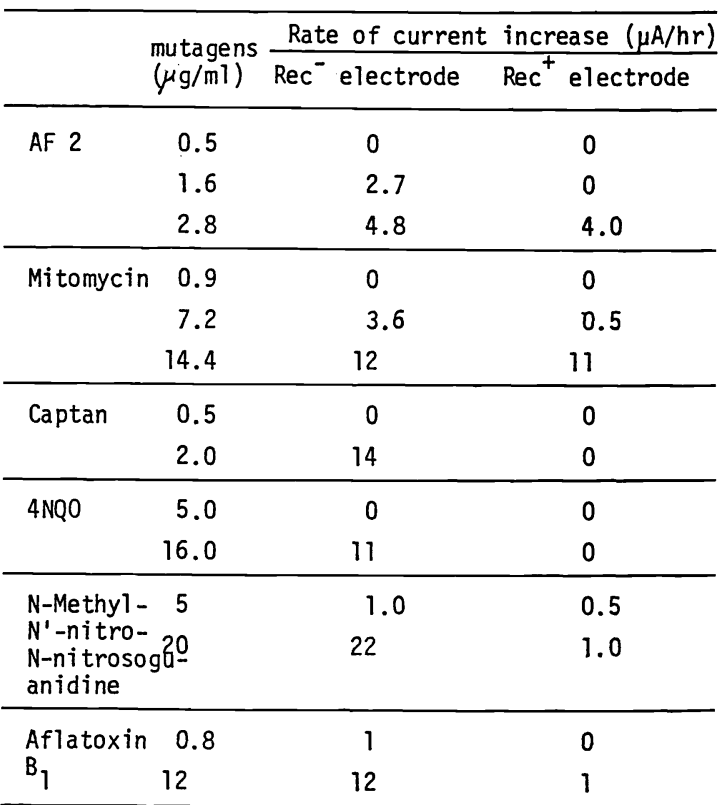

Fig.7. Schematic diagram of the electrode system for rapid detection of chemical mutagens

1: Recorder, 2: $\mathrm{Pb}$ anode,

3: Teflon membrane, 4: B. subtilis Rec ${ }^{+}$,

5: B. subtilis $\operatorname{Rec}^{-}, 6:$ : t cathode,

7: Membrane filter

A sensor consisting of the aerobic recombination-deficient bacteria and the oxygen electrode can be applied to the preliminary screening of chemical mutagens and carcinogens. The recombination-deficient strain B. subtilis M45 Rec $^{-}$and the wild strain B. subtilis H17 Rec ${ }^{+}$were employed for experiments. B. subtilis Rec $\mathrm{C}^{-}$and $\operatorname{Rec}^{+}$were immobilized onto a porous acetylcellulose membrane. The bacteria membrane was fixed on a Teflon membrane of the oxygen electrode. The microbial electrode system is shown in Figure 7. The electrode system consisted of two microbial electrodes: the electrode of $B_{\text {. }}$ subtilis Rec ${ }^{-}$(Rec- electrode) and the electrode of $B$. subtilis $\operatorname{Rec}^{+}$(Rec ${ }^{+}$electrode). Each electrode was composed of immobilized bacteria and an oxygen electrode.

When the Rec ${ }^{-}$and Rec ${ }^{+}$electrodes were inserted into the glucosebuffer solution $\left(0.3 \mathrm{~g} 1^{-T}\right.$ glucose), steady-state currents were obtained. Then, $A F-2$, a famous mutagen, was added to the solution. After 20-40 min, the current of the $\mathrm{Rec}^{-}$electrode began to increase giving a sigmoidal curve. On the other hand, the current of the Rec ${ }^{+}$electrode did not increase. The rate of current increase is a measure of the mutagen concentration and is most easily measured as the linear slope at the midpoint of the sigmoidal curve. Table 3 summarizes the response of the electrode system to various typical chemical mutagens. When chemical mutagens such as AF-2, mitomycin, Captan, 4NQO, N-methyl-N'-nitro-Nnitrosobuanidine, and aflatoxin $B$ were added to the glucose-buffer solution, the rates of the current increase of the Rec ${ }^{-}$and Rec ${ }^{+}$ electrodes were measured. The current of the Rec electrode markedly increased when these reagents were added to the system. Therefore, the mutagenicity of chemicals can be estimated with the electrochemical system.

The relationships between the rate of current increase of the Rec electrode and the concentration of $\mathrm{AF}-2$ and mitomycin were examined. Linear relationships were obtained in the range over $1.6-2.8 \mu \mathrm{g} \mathrm{ml^{-1 }}$ for $A F-2$ and $2.4-7.3 \mu \mathrm{g} \mathrm{ml}^{-1}$ for mitomycin. Such responses were not obtained when the antibiotics, respiration inhibitors, and bactericide were employed to the sensor. 
The electrochemical method is different, in principle, from the conventional streak method. Inhibition of growth is measured by the conventional "rec-assay" , whereas decrease of the cell number is measured from respiration activity of immobilized bacteria by the electrochemical method. Since the respiration of bacterial cells is directly and immediately converted to an electric signal, the preliminary screening of mutagens is possible within a hour. Moreover, the microbial sensor system employs a homogeneous suspension. Consequently, the sensitivity of the microbial sensor is higher than the "rec-assay" and the Ames test. The minimum measurable mutagen concentration is $1.6 \mu \mathrm{g} \mathrm{ml}^{-1}$ by the microbial sensor and $5.0 \mu \mathrm{g} \mathrm{ml}$ by the "rec-assay" and $10^{-1} \mathrm{gg} \mathrm{ml}^{-1}$ by the Ames test for $\mathrm{AF}-2$.

As described above, the recombinant-deficient (Rec-) bacteria are killed with mutagens. Therefore, a new bacteria membrane is needed for each analysis; but the preparation and exchange of a bacteria membrane are very easy and replacement takes only $1 \mathrm{~min}$. Moreover, the bacteria can be stored for 6 months at $-20^{\circ} \mathrm{C}$. The electrode current was reproducible within $5 \%$ in the buffer solution containing $1 \mathrm{~g} \mathrm{l}^{-1}$ glucose when the bacteria membrane used for analysis was replaced with a new membrane prepared from the stock bacteria.

The microbial electrode system appears promising and attractive for use in the routine preliminary screening of mutagens and carcinogens.

\section{REFERENCES}

1. I. Karube and S. Suzuki, Applied Biochemistry and Biotechnology, p.281, Academic Press, New York (1984)

2. I.Karube, Biotechnology \& Genetic Engineering Reviews, p.313, Newcastle upon Tyne (1984)

3. I. Karube and S. Suzuki, Enzymes and Immobilized Cells in Biotechnology, p.205, The Benjamin/Cumming Publishing Co. Inc., (1985)

4. M.Hikuma, H. Suzuki, T. Yasuda, I. Karube and S. Suzuki, European. J. Appl. Microbial. Biotechnol., 9, 305 (1980)

5. M. Hikuma, H. Obana, T. Yasuda, I. Karube and S. Suzuki, Enzyme Microbial Technol.., 2, 234 (1980)

6. S. Suzuki and I. Karube, Enzyme Engineering., 4, 329 (1978)

7. M. Hikuma, H. Suzuki, T. Yasuda, I. Karube and S. Suzuki, European. J. Appl. Microbiol. Biotechnol., 8, 289 (1979)

8. K.W. Fung, S.S. Kuan, H.Y. Sung and G.G. Guilbault, Anal. Chem., 51, 2319 (1979)

9. C.P. Pui, G.A. Rechnitz and R.F. Miller, Anal. Chem., 52, 1020 (1980)

10. M. Hikuma, T. Kubo, T. Yasuda, I. Karube and S. Suzuki, Anal. Chem., $\underline{52,}$ $1020(1980)$

11. I. Karube, T. Okada and S. Suzuki, Anal. Chem., 53, 1852 (1981)

12. T. Okada, I. Karube and S. Suzuki, Anal. Chim. Acta, 135, 159 (1982)

13. A.C. Stern, Air Pollution(3rd ed.), p. 259, Academic Press, New York (1976)

14. I. Karube, T. Okada, S. Suzuki, H. Suzuki, M. Hikuma and T. Yasuda, European J. Appl. Microbiol. Biotechnol., 15, 127 (1983)

15. I. Karube, S.Sogabe, T. Matsunaga and S. Suzuki, European J. Appl. Microbiol. Biotechnol., 17, 216 (1983)

16. T. Matsunaga, I. Karube and S. Suzuki, European J. Appl. Microbiol. Biotechnol., 10, 235 (1980)

17. I. Karube, T. Nakahara, T. Matsunaga and S. Suzuki, Anal. Chem., 54, $1725(1982)$ 